\title{
http://dx.doi.org/10.18778/2080-8313.18.08
}

Katarzyna Śliwak

(Uniwersytet Wrocławski

Wydział Nauk Historycznych

i Pedagogicznych, Instytut Historii)

\section{ZRZESZENIE NAUCZYCIELSTWA POLSKIEGO W IRANIE W LATACH 1943-1945}

$\mathrm{P}$ ierwsza polska organizacja związkowa nauczycieli została założona na terenie Galicji w 1905 r. podczas zjazdu w Pilaszkowie. Nazwano ją Związkiem Nauczycieli Ludowych. W niedługim odstępie czasu powstały kolejne: Polski Związek Nauczycielski oraz Stowarzyszenie Nauczycielstwa Polskiego, funkcjonujące pod zwierzchnictwem długoletniego prezesa Stanisława Nowaka. Po odzyskaniu przez Polskę niepodległości w 1918 r. w każdym byłym zaborze konstytuował się oddzielny związek nauczycielski, który reprezentował daną opcję polityczną. W 1930 r. ustanowiono jednolity Związek Nauczycielstwa Polskiego, który w obliczu działań wojennych 1939 r. został przekształcony w Tajną Organizację Nauczycielską ${ }^{1}$. Na skutek okupacji niemieckiej i sowieckiej nauczyciele, którzy znaleźli się na emigracji, dążyli do stworzenia ram organizacji związkowej, czego najlepszym przykładem była postawa tej grupy społecznej w Iranie.

Iran (do 1935 r. - Persja) był państwem, do którego w okresie dwudziestolecia międzywojennego przybywały dość liczne zorganizowane grupy Polaków. W związku z tym polskie służby zagraniczne zdecydowały się na powołanie w Teheranie Poselstwa RP. Stało się to w 1925 r. Na stanowisko posła został wyznaczony Stanisław Hempel, a w 1938 r. zastąpił go Jan Karszo-Siedlewski². Rola Poselstwa diametralnie wzrosła w 1942 r., kiedy to w wyniku podpisanego układu Sikorski-Majski ewakuowano do Iranu ok. 115 tys. ${ }^{3}$ ludności polskiej

\footnotetext{
${ }^{1}$ Zob. B. Grześ, Związek Nauczycielstwa Polskiego od korzeni po wspótczesność, Warszawa 2000.

2 Jan Karszo-Siedlewski (1891-1955) - polski dyplomata, konsul RP w Opolu, pracownik placówek dyplomatycznych w: Bejrucie, Charkowie, Kijowie, Moskwie, Pradze i Teheranie. Przed zakończeniem działań wojennych wyjechał do centrali MSZ Rządu Polskiego w Londynie, gdzie został zastępcą sekretarza generalnego. Po 1945 r. przebywał na terenie Wielkiej Brytanii. Zob. więcej w: J. Karszo-Siedlewski, [w:] Kto byt kim w Drugiej Rzeczypospolitej, red. J. Majchrowski, G. Mazur, K. Stepan, Warszawa 1994, s. 99.

${ }^{3}$ Por. J. Wróbel, Uchodźcy polscy ze Związu Sowieckiego 1942-1950, Łódź 2003, s. 42; J. Draus, Oświata i nauka polska na Bliskim i Środkowym Wschodzie 1939-1950, Lublin 1993, s. 23.
} 
z ZSRR. W tej grupie, oprócz ogromnej liczby dzieci i młodzieży, znaleźli się również zawodowi nauczyciele, którzy byli odpowiedzialni za organizację polskiego szkolnictwa.

Pierwszą agendą oświatową na terenie Iranu była powołana 3 kwietnia 1942 r. Delegatura Ministerstwa Pracy i Opieki Społecznej (MPiOS) z siedzibą w Teheranie (zwana także Delegaturą Rządu Polskiego ds. Opieki nad Ludnością Cywilną Ewakuowaną z Rosji). Na jej czele stanął Wiktor Styburski ${ }^{4}$. W 1943 r. ten urząd przejął Franciszek Haluch ${ }^{5}$, wcześniejszy zastępca Styburskiego.

Organem doradczym w sprawach oświaty była Komisja Szkolna pod kierownictwem Stanisława Sztaby. Podzielona ona była według kompetencji jej członków. Szkolnictwo powszechne i przedszkola przekazano pod nadzór Piotra Piałuchy oraz Emilii Świżewskiej, szkolnictwo średnie - S. Sztaby i Emilii Drozdowskiej, szkół i kursów zawodowych - Honoraty Rojanowskiej, natomiast Anieli Kubickiej powierzono opiekę nad byłymi dyrektorami szkół zawodowych ${ }^{6}$. Delegatura MPiOS - z uwagi na rozległy pod względem terytorialnym nadzór - realizowała swoje zadania dzięki Ekspozyturom w Isfahanie, Ahwazie, Meszedzie?

Skala obowiązków i szereg kompetencji Delegatury MPiOS spowodowały, iż stojący na czele MPiOS rządu londyńskiego Jan Stańczyk wypowiedział swoją opinię na ten temat w piśmie do gen. Hallera - kierownika Urzędu Oświaty i Spraw Szkolnych (UOiSS), aby te sprawy przekazać kierowanej przez niego agendzie $^{8}$. Problem ten poddano dyskusji we wrześniu 1942 r., podczas której szereg działaczy MPiOS dążyło do przeforsowania zdania, iż zarządzanie oświatą dalej winno leżeć w kompetencjach tej jednostki. Szansa na utrzymanie tego stanu została zaprzepaszczona w momencie zmiany stanowiska przez prof. Stanisława Kota: z Ambasadora RP w ZSRR na Ministra Stanu - Pełnomocnika Rządu RP na Wschodzie, który optował za powołaniem Delegatury UOiSS 9 .

${ }^{4}$ Wiktor Styburski (1902-1984) - ekonomista, pracownik Banku Polskiego. We wrześniu 1939 r. brał udział w ewakuacji złota polskiego do Rumunii. Delegat MPiOS w Teheranie oraz Delegat Rządu ds. ewakuacji ludności cywilnej. Zob. E. Raczyński, W sojuszniczym Londynie, Londyn 1960, s. 145-146.

5 Swą funkcję pełnił do 1 X 1944 r., kiedy to został Inspektorem Opieki MPiOS w Palestynie, Syrii i Libanie. Zob. K. Śliwak, Delegatura MPiOS w Teheranie w latach II wojny światowej-charakterystyka działań edukacyjnych dla polskich uchodźców, [w:] Ogrody nauk i sztuk. Szkice, studia i interpretacje na pograniczach nauk, red. A. Kobylarek, Wrocław 2015, t. 5, s. 262-263.

${ }^{6}$ Archiwum Akt Nowych (dalej: AAN), zespół akt: Poselstwo RP w Teheranie, sygn. 592/42, Sprawozdanie z działalności szkolnictwa w okresie od 10 IV do 15 IX 1942 r., bp.

7 AAN, zespół akt: Ministerstwo Pracy i Opieki Społecznej (dalej: MPiOS), sygn. 131/52, Sprawozdanie Delegatury MPiOS w Teheranie od 1 do 30 XI 1942 r., bp; J. Draus, dz. cyt., s. 55-57.

${ }^{8}$ Archiwum Instytutu Polskiego i Muzeum gen. Sikorskiego w Londynie (dalej: IPMS), zespół akt: Ministerstwo Wyznań Religijnych i Oświecenia Publicznego (dalej: MWRiOP), sygn. A.19.I./14, Pismo z 19 VI 1942 r. do UOiSS w sprawie pomocy powstajacym szkołom, k. 1.

9 Tamże, sygn. A.19.III./10, Pismo S. Rzerzychy [b.d.], k. 1. 
W 1943 r. sytuacja Delegatury MPiOS skomplikowała się jeszcze bardziej, bowiem tamtejsze władze przystąpiły do organizacji kolejnej placówki ministerialnej - Ministerstwa Spraw Wewnętrznych (MSW) w Teheranie. W marcu 1943 r. Jerzy Górszczyk został mianowany na stanowisko Kierownika tegoż ministerstwa ${ }^{10}$. J. Górszczyk od pierwszych dni swoich rządów w MSW nie mógł porozumieć się z F. Haluchem. Początkowo ta nowa jednostka nie posiadała statutu, w którym ściśle uregulowane byłyby jej kompetencje. Kierownik poinformował o tym Ministra Stanu ds. Bliskiego Wschodu w rządzie londyńskim - Henryka Strasburgera. On opracował dla Górszczyka Statut MSW, który został podpisany przez wyżej wymienionych oraz Halucha w Kairze w grudniu 1943 r. ${ }^{11}$ Postanowień podpisanych w Egipcie nie zaakceptował Minister Pracy i Opieki Społecznej w Londynie J. Stańczyk, który stwierdził w nim dublowanie kompetencji Delegata MPiOS. Jego zdaniem Kierownik MSW nie powinien kontrolować porządku w obozach, ani mieć dostępu do informacji przeznaczonych specjalnie dla MPiOS. Górszczyk oskarżył Delegaturę MPiOS, o to, że mimo, iż była ona placówką ministerialną, zbierała informacje polityczne, a jego osobę nawet inwigilowała $^{12}$. Swoją pozycję w tym konflikcie interesów wzmocniła żona J. Górszczyka - działaczka społeczna i nauczycielka Wanda Szuszkiewicz-Górszczyk, której postawa i zaangażowanie szybko zostało dostrzeżone w niedługim okresie po przekształceniu się Delegatury UOiSS w Delegaturę Ministerstwa Wyznań Religijnych i Oświecenia Publicznego (MWRiOP) w Iranie ${ }^{13}$.

Po śmierci gen. Sikorskiego, w dniu 14 lipca 1943 r. zostało powołane Ministerstwo Wyznań i Oświecenia Publicznego na czele z ministrem ks. Z. Kaczyńskim. Kaczyński 4 sierpnia 1943 r. ${ }^{14}$ wydał akt będący podstawą dalszego funkcjonowania Delegatur MWRiOP. Od tego momentu Delegatura z siedzibą w Teheranie i Delegatem MWRiOP Stanisławem Rzerzychą ${ }^{15}$ (od czerwca 1943 r. był Delegatem UOiSS $)^{16}$ objęła swym nadzorem pedagogicznym także Indie. Poszczególni

${ }^{10}$ J. Pietrzak, Polscy uchodźcy na Bliskim Wschodzie w latach drugiej wojny światowej, Łódź 2012, s. 277.

${ }^{11}$ W Statucie widniał zapis o kompetencjach Kierownika MSW - „mógł on dokonywać inspekcji politycznej w obozach uchodźczych oraz otrzymywać od Delegata MPiOS i starostów obozów informacji politycznych". Zob. IMPS, zespół akt: Prezydium Rady Ministrów. Archiwum Libermanowej (dalej: PRM-AL), sygn. PRM.L/67, Pismo z 11 XII 1943 r. J. Górszczyka do W. Banaczyka, bp.

12 Tamże, Depesze J. Górszczyka do W. Banaczyka z 20 i 25 I 1944 r., bp.

${ }_{13}$ IPMS, MWRiOP, sygn. A.19.III./10, Pismo S. Rzerzychy [b.d.], k. 1.

14 Tamże, sygn. A.19.II./52, Rozporządzenie MWRiOP w sprawie utworzenia Delegatur z 4 VIII 1943 r., k. 1.

${ }^{15}$ W styczniu 1945 r. S. Rzerzycha został przeniesiony na stanowisko Delegata MWRiOP w Jerozolimie, a na jego miejsce wyznaczono P. Piałuchę. Zob. tamże, sygn. A.19.II./135, Pismo P. Pialuchy do MWRiOP z 27 III 1945 r., bp.

${ }^{16}$ W czerwcu 1943 r. zdymisjonowano wcześniejszego Delegata UOiSS na teren Iranu, Palestyny i Egiptu -Józefa Follprechta, byłego dyrektora gimnazjum w Nadwórnej oraz Kierownika 
Delegaci MWRiOP i MPiOS mieli ściśle współpracować ze sobą, zwłaszcza W sprawach dotyczących oświaty pozaszkolnej ${ }^{17}$, jednak nominacja Rzerzychy zrodziła szereg dyskusji w wśród polityków związanych z Delegaturą MPiOS ${ }^{18}$.

Trudności w pierwszym okresie funkcjonowania Delegatury MWRiOP wiązały się z wieloma problemami. Pierwszy z nich łączył się z kadrą pedagogiczną, która najczęściej wywodziła się z grona uchodźców i nie posiadała pełnych kwalifikacji. Do pracy nauczycielskiej były powoływane ochotniczki z Pomocniczej Służby Kobiet. W listopadzie 1943 r. utworzono kurs dokształcający dla nauczycieli szkół powszechnych w Teheranie. Jego program obejmował zajęcia ze wszystkich przedmiotów szkolnych, wiedzy o Polsce i wychowania fizycznego ${ }^{19}$. Organizacja takich kursów miała na celu zachęcić kandydatów do zawodu nauczyciela do podnoszenia kwalifikacji, gdyż nauczycielska posada nie była dobrze płatna - miesięczny zarobek wynosił ok. czterech funtów ${ }^{20}$. Wynagrodzenie nauczycieli rosło wraz z długością stażu pracy lub nabyciem pełnych kwalifikacji.

Brak podręczników był kolejnym problemem dla nauczycieli, jak również kwestią do rozwiązania przez MWRiOP w Londynie, które przesyłało książki. Oprócz ich druku w Palestynie, koniecznością stało się ich wydawanie na miejscu. Delegat MWRiOP w Teheranie S. Rzerzycha w swoim piśmie wyrażał podziw dla wielu nauczycieli, którzy (mimo niedostatku książek) starali się na bieżąco zdobywać środki na ich wydruk ${ }^{21}$. Nauczyciele mimo wszelkich niedogodności i braku bezpośredniego kontaktu (odległości między Teheranem, Isfahanem, Ahwazem a Meszedem, gdzie przebywali uchodźcy były ogromne) zdecydowali się utworzyć organizację związkową, która miała stanowić ich prawa i obowiązki zawodowe.

Referatu Szkolnego. Zob. IPMS, zespół akt: Najwyższa Izba Kontroli (1939-1992) (dalej: NIK), sygn. A.57./12, Odpis listu z 15 IV 1943 r. gen. J. Hallera - nominacja J. Follprechta na Delegata Urzędu Oświaty i Spraw Szkolnych w Palestynie z zasięgiem na Egipt, bp.; IPMS, MWRiOP, sygn. A.19.I./14, Pismo gen. J. Hallera do S. Kota z 6 II 1942 r. w sprawie szkolnictwa na Wschodzie, k. 1.

${ }^{17}$ IPMS, zespół akt: Delegatura MWRiOP w Palestynie (1942-1945), sygn. A.74./28, Zarzqdzenie Z. Kaczyńskiego z 4 VIII 1943 r., bp.

${ }^{18} \mathrm{Na}$ prośbę Ministra J. Stańczyka organizacja agend rządowych miała nie być zmieniana, a konsultacjom z MPiOS powinny podlegać propozycję obsadzania poszczególnych stanowisk. Generał Haller miał w tej sprawie odmienne zdanie, przeciwstawiał się nadzorowi MPiOS nad MWRiOP. Zob. IPMS, MWRiOP, sygn. A.19.I./14, Pismo J. Stańczyka do UOiSS z 9 XI 1942 r., bp.

19 J. Wróbel, dz. cyt., s. 77.

${ }^{20}$ W roku 1944 r. uposażenie nauczycieli pracujących na uchodźstwie wzrosło i wahało się od 10 do 20 funtów. Dla porównania miesięczne uposażenie maszynistki w Delegaturze MPiOS wynosiło 30-35 funtów, maszynistki w obozie ok. ośmiu funtów, natomiast sanitariuszki ok. dziewięciu funtów. Zob. IMPS, MWRiOP, sygn. A.19.II./6, Normy wynagrodzeń nauczycieli szkót rozmaitych typów oraz pracowników administracji szkolnej w Iranie, k. 1; AAN, MPiOS, sygn. 131/92, Memoriat SL $w$ Iranie [b.d.], k. 10.

${ }^{21}$ AAN, MPiOS, sygn. 131/15, Sprawozdanie S. Rzerzychy z 15 II 1944 r., bp. 
Koniec roku 1943 to czas tworzenia się pierwszych związków nauczycielskich na terenie Iranu. Wanda Szuszkiewicz-Górszczyk (nauczycielka z Teheranu) w swoim rocznym sprawozdaniu podkreślała różnorodność kwalifikacji, przynależności politycznej oraz braku wcześniejszej współpracy między nauczycielami pracującymi w Iranie ${ }^{22}$. Sądziła, iż było to spowodowane niedostateczną komunikacją, jak również słabym poparciem ich działań w MPiOS oraz MWRiOP. Dopiero jej wizyta w Isfahanie oraz spotkanie z inspektorem szkolnym Adamem Lorenowiczem spowodowało założenie miejscowego koła ZNP. Początkowo planowano wspólne zebranie, na którym miał zostać wybrany Prezes, a wśród kandydatów do objęcia tej funkcji znajdował się m.in. Franciszek Dąbrowski. Na skutek braku transportu do Isfahanu ${ }^{23}$, tamtejsze władze same ustaliły skład zarządu związku. Prezesem został powołany Adam Krzewiński, a do zarządu wszedł A. Lorenowicz (mimo sprzeciwu S. Rzerzychy, który twierdził, iż inspektor szkolny nie może zajmować innych stanowisk związanych z zarządzaniem oświatą) oraz Maria Krzyżanowska - Dyrektor Państwowego Liceum i Gimnazjum w Isfahanie ${ }^{24}$.

Zrzeszenie Nauczycieli Polaków w Isfahanie rozpoczęło działalność z dniem 28 listopada 1943 r. Liczba członków wynosiła 108 osób, co stanowiło 98\% wszystkich polskich nauczycieli pracujących na terenie Iranu. Celem jej utworzenia było dokształcanie kadr oświatowych oraz udzielanie wsparcia w wychowaniu młodych Polaków. Zostało ono podzielone na trzy sekcje: naukową, ekonomiczną oraz imprezową. Na zebrania zapraszano znane osoby - m.in. gościło Ministra Strasburgera, jak również wspomagano finansowo jeńców polskich w Niemczech itp. ${ }^{25}$

Początkowo nowo powstałe ZNP w Isfahanie musiało walczyć z szeregiem problemów. Wśród zrzeszonych w nim nauczycieli byli tacy, którzy bojkotowali zebrania i nakłaniali do wystąpienia ze stowarzyszenia. Działania władz wobec ZNP w Isfahanie były nieprzychylne. Delegatura MPiOS dążyła do rozmontowania tworzonych kół namawiając nauczycieli do wyjazdu do Afryki. Tymczasem W. Szuszkiewicz-Górszczyk zmierzała do podtrzymania dobrego kontaktu z Krzewińskim oraz Krzyżanowską widząc, że mają oni poparcie Rzerzychy, któremu też zależało na stworzeniu jednej organizacji skupiającej w swoich sze-

${ }^{22}$ Tamże, sygn. 131/92, Sprawozdanie z 1 VIII 1944 r. „O wzajemnych stosunkach między organizacjami zrzeszonego nauczycielstwa w Iranie", k. 1.

${ }^{23}$ Isfahan był oddalony od Teheranu o $426 \mathrm{~km}$. Nie można było do niego dotrzeć drogą kolejową, natomiast podróż samochodem zajmowała dwa dni. Zob. IMPS, MWRiOP, sygn. A.19.II./8, Sprawozdanie ze stanu szkolnictwa na terenie Iranu w okresie 1 II - 30 IV 1944 r., k. 2.

${ }^{24}$ A. Lorenowicz został odwołany ze stanowiska inspektora szkolnego decyzją ZNP w Wielkiej Brytanii. Zob. AAN, MPiOS, sygn. 131/92, Sprawozdanie z 1 VIII 1944 r. „O wzajemnych stosunkach między organizacjami zrzeszonego nauczycielstwa w Iranie", , k. 2

25 IPMS, MWRiOP, sygn. A.19.II./62, Sprawozdanie z dotychczasowej działalności Zrzeszenia Nauczycieli Polaków w Isfahanie z 15 marca 1944 r., k. 1. 
regach polskich nauczycieli w Iranie. W szeregach ZNP w Isfahanie - według Szuszkiewicz-Górszczyk - doszło do nadużyć finansowych. Krzewiński wysyłał $\mathrm{w}$ tej sprawie szereg pism do ZNP w Londynie (związek kosztowało to 34 funty), w których chciał dyskredytować Szuszkiewicz-Górszczyk. Związkowa Komisja Rewizyjna nie stwierdziła jakichkolwiek nieprawidłowości ${ }^{26}$.

Szuszkiewicz-Górszczyk usilnie dążyła do konsolidacji środowiska nauczycielskiego. Do pierwszego nawiązania współpracy między ZNP w Teheranie oraz Isfahanie doszło przez kontakt z Dąbrowskim, który został przeniesiony do Isfahanu, gdzie objął funkcję Kierownika szkoły obozowej. Niedługo później, w maju 1944 r., nastąpiło połączenie organizacji nauczycielskich z Teheranu, Isfahanu, Ahwazu. W jego efekcie rozpoczęło działalność Zrzeszenie Nauczycieli Polaków w Iranie ${ }^{27}$. Zwierzchnią kontrolę nad Zrzeszeniem przejął Zarząd Główny ZNP w Londynie ${ }^{28}$.

Na przewodnicząca ZNP w Iranie została wybrana Wanda Szuszkiewicz-Górszczyk ${ }^{29}$. Oddziały zjednoczonej organizacji znajdowały się w Ahwazie oraz Teheranie. W Isfahanie działała „klika dwójarsko-narodowa" ${ }^{30}$ (chodziło tutaj o A. Krzewińskiego i A. Lorenowicza), której działania były popierane przez Delegata MPiOS F. Halucha i bardzo chwiejnego w swoich działaniach S. Rzerzychę. Zarząd ZNP w Isfahanie w zasadzie do końca działań wojennych nie uznawał przynależności do ZNP w Iranie (tak samo działał MPiOS z F. Haluchem na czele, gdyż posługiwał się dalej własnymi pieczęciami i wydawał pisma kierowane do nauczycieli w Isfahanie ${ }^{31}$.

Działania W. Szuszkiewicz-Górszczyk na rzecz nauczycieli polskich były wielokrotnie utrudniane przez Delegata MPiOS i jego zwolenników. Ta niechęć do Szuszkiewicz-Górszczyk wynikała oczywiście ze wcześniejszych zatargów F. Halucha z jej mężem. W styczniu 1945 r. J. Górszczyka powołano do służby wojskowej w Palestynie i tym samym dokonano zmiany Kierownika MSW ${ }^{32}$. Jego żona Wanda spodziewała się wówczas dziecka, toteż - aby zapobiec przeniesieniu Górszczyka - S. Mikołajczyk pisemnie interweniował u Premiera Arciszewskiego $^{33}$. Szef polskiego rządu pozostał jednak nieugięty. Swoją decyzję

${ }^{26}$ AAN, MPiOS, sygn. 131/92, Pismo do Komisji Badawczej Ministerstwa Sprawiedliwości $w$ Teheranie $z 10$ VI 1944 r., k. 1.

27 IPMS, PRM-AL, sygn. PRM.L/52, Depesza z 29 III 1944 r., k. 146.

${ }^{28}$ T. Radzik, Zrzeszenie Nauczycielstwa Polskiego Zagranica (1941-1991), Lublin 1992, s. 26.

29 IPMS, PRM-AL, sygn. PRM.L/52, Depesza z 7 II 1944 r., k. 86.

${ }^{30}$ Tamże, sygn. PRM.L/53, Depesza z 25 XI 1944 r., k. 188.

${ }^{31}$ AAN, zespół akt: Poselstwo RP w Teheranie, sygn. 592/42, Pismo K. Badera do Ministra z 15 V 1944 r., k. 1.

32 Jego miejsce zajął Witold Matkowski. Zob. Tamże, Telegram szyfrowany Z. Berezowskiego do Poselstwa RP w Teheranie z 25 I 1945 r., k. 88.

33 IPMS, zespół akt: Prezydium Rady Ministrów. Osobiste archiwum Premiera (1939-1945), sygn. PRM.169/21, Pismo S. Mikołajczyka do T. Arciszewskiego z 10 II 1945 r., k. 6. 
motywował następująco: „[Górszczyk] wszedł w ostry konflikt z miejscowym społeczeństwem i naraził na szwank powagę urzędu"34.

Wyjazd małżeństwa Górszczyków stał się nieunikniony, ale ZNP w Iranie, który mimo swej podległości Zarządowi Głównemu ZNP w Londynie, pozostał w swoich działaniach niezależny. Ponadto naczelne władze organizacji same nie chciały zbyt mocno ingerować w problemy ZNP, ponieważ doskonale wiedziały, iż jego członkowie prowadziły grę polityczną, której skutki ponieśli najbardziej aktywni działacze.

Katarzyna Śliwak

\section{THE POLISH TEACHER'S UNION IN IRAN IN YEARS 1943-1945}

In the article the author presents the activity of the Polish Teacher's Union in Iran in years 1943-1945. Poles who came to Iran from the USSR after the amnesty as a result of the Sikorski-Maisky agreement formed a particular Delegations, which was directed by the Polish government-in-exile in London: the Delegacy of the Ministry of Labour and Social Welfare, Internal Affairs and Religious Affairs and Public Education. The last one played a role in the creation of schools and Polish Teacher's Union, which was also contributed by Wanda Szuszkiewicz-Górszczyk.

Słowa kluczowe: Armia Andersa, deportacja, polscy nauczyciele, historia edukacji

Keywords: Anders' Army, deportation, Polish teachers, history of education

\section{BIBLIOGRAFIA}

\section{Źródla archiwalne:}

Archiwum Akt Nowych w Warszawie

Ministerstwo Pracy i Opieki Społecznej.

Poselstwo RP w Teheranie.

Archiwum Instytutu Polskiego i Muzeum gen. Sikorskiego w Londynie

Ministerstwo Wyznań Religijnych i Oświecenia Publicznego.

Najwyższa Izba Kontroli (1939-1992).

Prezydium Rady Ministrów. Archiwum Libermanowej.

Prezydium Rady Ministrów. Osobiste archiwum Premiera (1939-1945).

\section{Wspomnienia:}

Raczyński E., W sojuszniczym Londynie, Londyn 1960.

\footnotetext{
${ }^{34}$ Tamże, Pismo T. Arciszewskiego do S. Mikołajczyka z 27 II 1945 r., k. 8.
} 


\section{Opracowania:}

Draus J., Oświata i nauka polska na Bliskim i Środkowym Wschodzie 1939-1950, Lublin 1993.

Grześ B., Związek Nauczycielstwa Polskiego od korzeni po współczesność, Warszawa 2000.

Kto byt kim w Drugiej Rzeczypospolitej, red. J. Majchrowski, G. Mazur, K. Stepan, Warszawa 1994.

Pietrzak J., Polscy uchodźcy na Bliskim Wschodzie w latach drugiej wojny światowej, Łódź 2012.

Radzik T., Zrzeszenie Nauczycielstwa Polskiego Zagranica (1941-1991), Lublin 1992.

Śliwak K., Delegatura MPiOS w Teheranie w latach II wojny światowej-charakterystyka działań edukacyjnych dla polskich uchodźców, [w:] Ogrody nauk i sztuk. Szkice, studia i interpretacje na pograniczach nauk, t. 5, red. A. Kobylarek, Wrocław 2015.

Wróbel J., Uchodźcy polscy ze Związu Sowieckiego 1942-1950, Łódź 2003. 